\title{
一基礎研究から学ぶー
}

\author{
3. 遺伝子導入と発現シリーズ \\ バクテリアを利用した遺伝子導入とタンパク質の大量発現 $(2)$ \\ 松村 智裕 \\ 日本医科大学大学院医学研究科医科生物化学

\section{Gene Delivery and Expression Series} \\ Overexpression of Recombinant Protein in Bacterial Cells (2) \\ Tomohiro Matsumura \\ Division of Medical and Biological Chemistry, Graduate School of Medicine, Nippon Medical School
}

\begin{abstract}
The protein expression system in bacteria is widely used to overproduce recombinant proteins. Many established expression vectors are on the market. The Escherichia coli expression system is extremely useful for biochemical and biophysical analysis. Here, we describe the results of the expression of mammalian protein in E. coli and an experiment on the structural analysis of recombinant protein.
\end{abstract}

(日本医科大学医学会雑誌 2011; 7: 169-174)

Key words: expression vector, Escherichia coli, overexpression

\section{はじめに}

大腸菌をはじめとする原核生物を用いたタンパク質 発現系は長い歴史を持ち，操作が簡便であることから 広く用いられている. バクテリアでタンパク質を発現 させるべクターには，多くの種類が作製され市販され ている.なかでも大腸菌でタンパク質を大量に発現さ せる発現ベクターは, 細胞内でのコピー数や発現させ るプロモーターの強さなど，様々な改変がなされてい る. タンパク質を大量発現させる目的は, タンパク質 を高純度かつ大量に得ることであり，タンパク質の持 つ固有の機能を生化学的な手法で解析するためにあ る. 例えば，ゲノム解析などによって見つかる遺伝子 の一塩基多型 (Single Nucleotide Polymorphism, SNP）に扔いて，その機能の違いを解析するには，夕
ンパク質に部位特異的な変異を導入して個別に物性や 構造変化を解析することで，一残基の差異について詳 細な検討が可能となる。このような遺伝子組換えタン パク質の調製に大腸菌を用いると, 非常に簡便でかつ 迅速に研究できる。ここでは, 特に大腸菌内でタンパ ク質を作らせるための発現ベクターを利用した研究に ついて，実際に哺乳類の遺伝子を用いて発現させた害 験の結果を例に挙げて, 発現したタンパク質の解析結 果を示しながら，大腸菌発現系の有用性について述べ る.

\section{大腸菌発現ベクターの構造}

発現させたタンパク質をどのように利用するか，目 的に応じて利用可能な種々のベクターが開発されてい る. 大腸菌内でタンパク質の発現誘導をするプロモー

Correspondence to Tomohiro Matsumura, Division of Metabolism and Nutrition, Department of Biochemistry and Molecular Biology, Nippon Medical School, 1-1-5 Sendagi, Bunkyo-ku, Tokyo 113-8602, Japan E-mail: tm28@nms.ac.jp Journal Website (http://www.nms.ac.jp/jmanms/) 
ターとしてよく用いられているのは, lac オペロンを 応用した lac プロモーターおよびその派生のプロモー ターである. 培地にラクトースのアナログ化合物であ る IPTG（Isopropyl $\beta$-D-1-thiogalactopyranoside）を 添加することで遺伝子の発現を誘導でき，人為的に発 現をコントロールしやすい. これらのほか, 実際によ く用いられる発現ベクターとして, pET vectorの例 を挙げる ${ }^{1-3}$. pET vectorのシリーズには現在, 40 種 類以上のベクターがあり，詳細はカタログなどを参照 されたい. pET vector で用いられている発現プロモー ターは T7 バクテリオファージ由来であるため, 通常 の大腸菌内では遺伝子の発現は誘導されない. そのた め, 大腸菌にとって有害な遺伝子であっても比較的, 安定にクローニングできるという長所がある，構築し たベクターを用いてタンパク質を発現させるために は, T7 RNA ポリメラーゼ遺伝子を持つ宿主大腸菌 を利用する。この T7 RNA ポリメラーゼの発現誘導 にlacプロモーターが使われているため, 結果として pET vector 上の遺伝子も IPTGによってタンパク質 の発現誘導が可能となる。 pET vectorによるタンパ ク質の発現は非常に強力で, 大腸菌の全タンパク質の $50 \%$ 以上を占めることもある。

このほかに，温度に依存して発現が誘導されるべク ターも市販されている.このべクターでは大腸菌を低 温下（15ㄷ など）で培養することでタンパク質の発 現が誘導される ${ }^{4}$. 低温誘導の発現系では, 大腸菌自 身が持つタンパク質の発現が抑制されることで，より 高純度の発現タンパク質が得られることや, 低温によ りタンパク質のフォールディングが穏やかになること で, 発現させたタンパク質の可溶性の向上が期待でき る. 実際, pET vectorで封入体を生じてしまうケー スでも可溶性となる例が多くある.

また，細胞内は還元された状態にあるためシステイ ン残基のジスルフィド結合（S-S）を形成するタンパ ク質発現がうまくいかないことがある.これを改善す るために, ペリプラズムにタンパク質を分泌させるこ とで S-S 結合の形成を促進する発現べクターもある. このような発現ベクターの発展系として, グラム陽性 菌であるブレビバチルス（Bacillus brevis）で発現させ 菌体外にタンパク質を分泌させる発現べクターも市販 されている ${ }^{5}$.この系では発現させたタンパク質が菌 体外に分泌されることで大量に蓄積し, 発現効率の上 昇も期待できる.

\section{融合タンパク質の発現}

発現ベクターでは特別な配列（タグ配列）を本来の 遺伝子配列に結合させた融合タンパク質として発現さ せるべクターも多用されている。 よく使用される夕グ 配列としてヒスチジン（His）残基を 6 残基程度, 連 続してつなげたヒスチジンタグ (His-Tag) 配列があ る. His-Tag を結合させて発現させると, 金属イオン をカラムに固定させた金属アフィニティーカラムを利 用して, 比較的簡単な操作で純度の高いタンパク質を 精製でき, 非常に有用である. 同様に, 短いペプチド 配列で構成される夕グ配列に T7-tag, S-Tagなどが ある.ほかには, myc, HA, FLAGなどのぺプチド タグ配列がある．基本的にこれらのペプチドタグ配列 を持った融合タンパク質は, 抗体を利用したアフィニ ティーカラムを用いた精製が可能である.

ペプチドタグ配列以外にも，チオレドキシン $(\operatorname{Trx})$ やグルタチオン-S-トランスフェラーゼ（GST）といっ たタンパク質を融合させて発現するベクター ${ }^{6}$ 市販 されている.これらのタンパク質は大腸菌細胞内の量 が多く, 発現べクターによって大量発現させた時も安 定して可溶性画分に回収されることから，融合させた タンパク質の可溶性を上昇させることがある. Trx や GST が特異的に結合するアフィニティーカラムも 市販されているので, 精製も容易になる. ただし，ぺ プチドタグ配列に比べ分子量が大きい（Trxが約 11,000, GST が約 26,000）ことから, タンパク質の高 次構造や酵素活性などに影響を及ぼすことが考えられ るため, 発現タンパク質の解析結果の評価には注意を 要する.

ペプチドタグ配列やタンパク質タグ配列を含む融合 タンパク質発現ベクターは, 融合させるタンパク質と の間の長さ（スペーサー配列）や位置（N-末端， C-末 端のどちらに融合させるか) を変えることで劇的に改 良されることもあるので，様々な条件を検討するとよ い. また, 融合させたタグ配列部分を切り離せるよう に特異的なプロテアーゼの認識配列を含む発現べク ターも多い.このようなべクターは，夕グ配列を利用 してアフィニティーカラムで精製した後, プロテアー ゼの部分分解によってタグを切断することで，より本 来の構造に近いタンパク質として精製することも可能 である。 


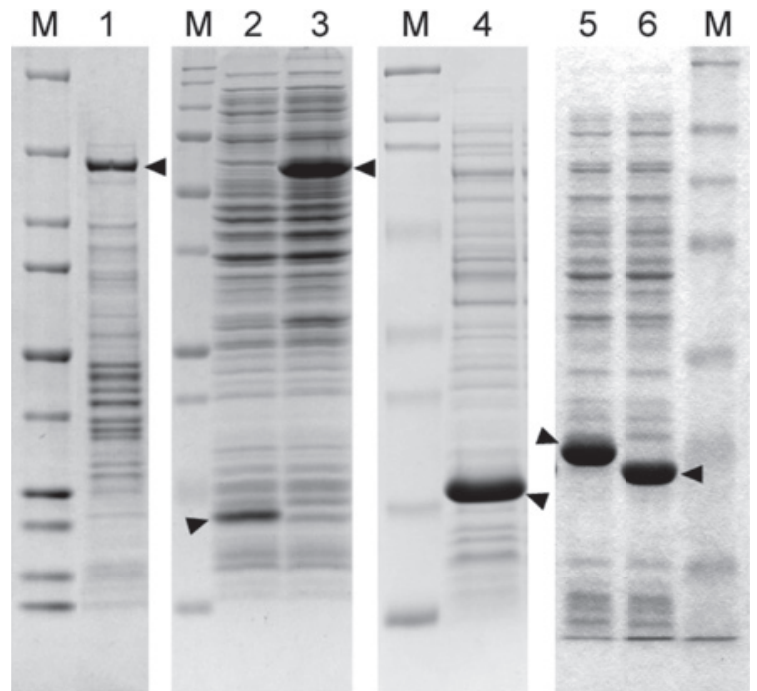

Fig. 1 種々の発現ベクターを用いたタンパク質発現 実験

ヒト cDNA を発現ベクターに組み込み, タン パク質を発現誘導させた大腸菌をSDS-PAGE で解析した. lane 1; pTrc99A vector, lane 2, 3 ; pET15B vector, lane 4 , pET30a vector (N-末端His-Tag), lane 5 ; pET28a vector (N末端 His-Tag), lane 6 ; pET30a vector, $\mathrm{M}$; 分子量マーカー

レーン 5 および 6 はペルオキシレドキシン

（Prx I）の発現を確認した.

\section{大腸菌での大量発現実験}

以下に哺乳類のタンパク質を大腸菌で発現させる場 合を例として実際の実験結果を示していく．タンパク 質を大腸菌で発現する際に成功する可能性が高いの は，もとの細胞で可溶性画分に分布しているような夕 ンパク質である. 可溶性タンパク質であっても，核に 遺伝子がコードされ細胞内のオルガネラ（ミトコンド リアなど）に輸送されるタンパク質の場合は，輸送の ためのシグナルペプチドが除去されて成熟型のタンパ ク質になることが多いため, 大腸菌で発現させる際に はあらかじめこのシグナルペプチドを除いて発現させ るほうが成功する確率が上がる。一般に，膜タンパク 質の大量発現は大腸菌には不適なことが多い。これは 大腸菌にはオルガネラが存在せず，膜タンパク質の蓄 積の場となる細胞膜が物理的に少ないため, タンパク 質が安定に発現できないことが多いためである。ささら に，例えば分泌タンパク質の多くは糖鎖による修飾を 受けているが, 特殊な発現系を除いて大腸菌内で糖鎖 修飾することはできない.

Fig. 1 に実際にわれわれの研究室で行った大腸菌で
A

B
123

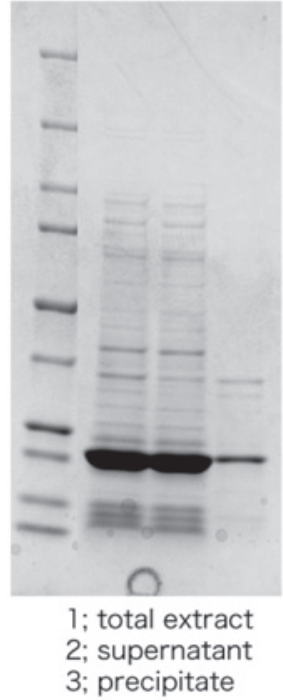

123

4

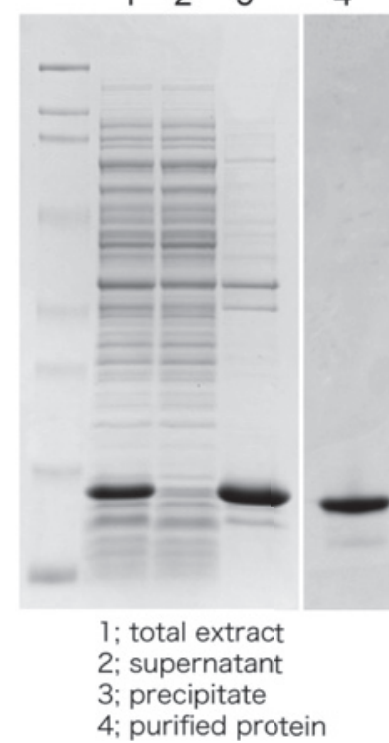

Fig. 2 大腸菌で発現させたタンパク質の可溶性 タンパク質を発現誘導させた菌体を超音波破砕により 抽出し, 15,000 g の遠心で上清と沈殿に分離した。 $\mathbf{A}$ ： タンパク質 (Prx I) は大部分が可溶性で発現 (lane2). B : プロテオーム解析で同定された機能未知の $12 \mathrm{KDa}$ タンパク質を, $\mathrm{N}$ 末端に His-Tag 付きで発現させた ところ, 組換えタンパク質のほぼすべてが封入体を形 成し沈殿した (lane3). 沈殿画分のタンパク質をリ フォールディングさせ可溶性タンパク質として精製 (lane4)

発現したタンパク質を抽出して電気泳動によって解析 した実験の例を挙げる。いずれの場合でも SDS-ポリ アクリルアミドゲル電気泳動（SDS-poly-acrylamide gel electrophoresis；SDS-PAGE）上で目的のタンパ ク質が確認できるほど，大量に発現していることがわ かる. Fig. 2 では，大量発現させたタンパク質を抽出 し，可溶性で発現しているかどうかを確認した結果を 示した。いずれの場合も非常に大量のタンパク質が発 現しているが，大量に発現しても，可溶性画分に回収 されないケースもある(Fig. 2，B)。このような場合， 多くは封入体（inclusion body）を形成して大腸菌細 胞内でタンパク質が沈殿している. 封入体に回収され たタンパク質であっても，尿素やグアニジン塩酸など の変性剂を用いて可溶化し，透析によって徐々に変性 剂の濃度を下げながらタンパク質のフォールディング を行って可溶化する方法もある. Fig. 2, B ; lane 4 は封入体に回収されたタンパク質を $8 \mathrm{M}$ 尿素, $10 \mathrm{mM}$ ジチオスレイトール（dithiothreitol；DTT）を含む Tris 緩衝液で可溶化した後，透析によって尿素の濃 度を徐々に低下させ, 最終的に Tris 緩衝液のみの溶 液で可溶性のタンパク質として回収し，精製に成功し 


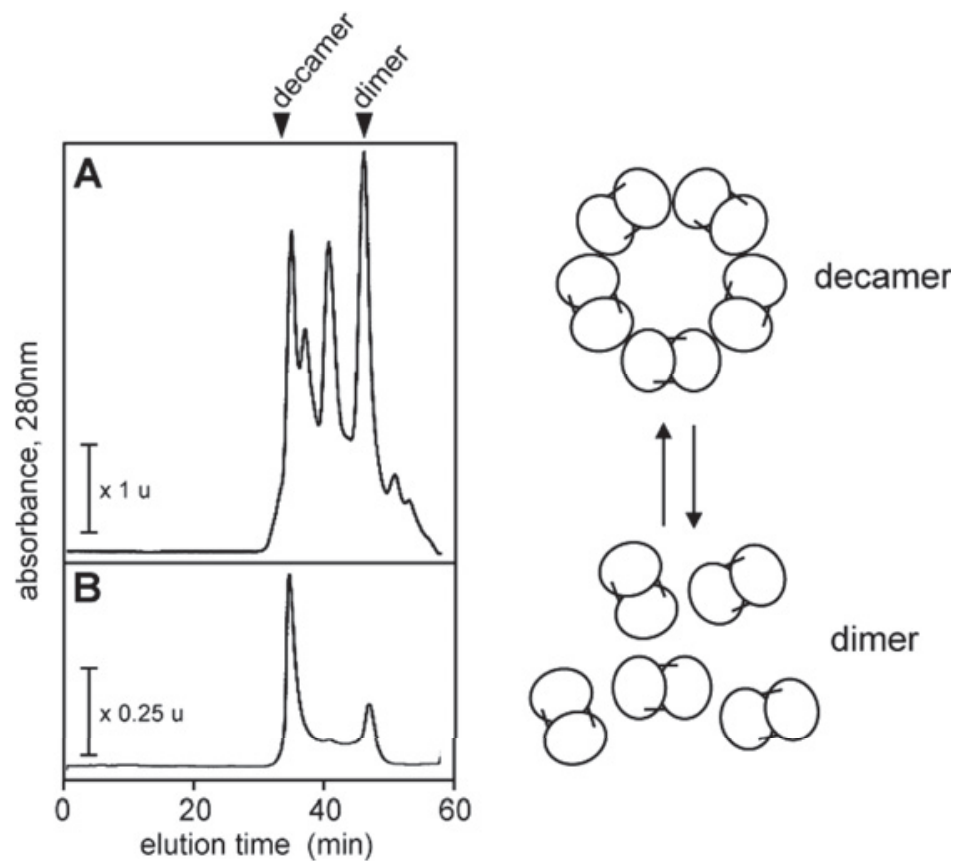

Fig. 3 Prx I 組換え蛋白質の HPLCによるゲルろ過解析 $\mathbf{A}$ ：精製した組換えタンパク質をゲルろ過カラムで分取. B : A で分取 した 10 量体の画分を再度ゲルろ過カラムで分離すると 10 量体に加え 2 量体の分子が存在した

た例である。

タンパク質が封入体を形成してしまう理由として， 発現のためのプロモーターが強力であるため, 短時間 にタンパク質が高濃度になることで凝集している可能 性もあるので, 発現させる際の培養温度を低温にした り，シャペロンタンパク質を共発現させる，といった 手法で改善される場合もある.

\section{発現させたタンパク質の解析}

われわれの研究室において大量発現に成功した例と して, ペルオキシレドキシン (peroxiredoxin ; Prx) を用いた研究を以下に示す．抗酸化タンパク質の一つ $\operatorname{Prx}$ は, タンパク質ファミリーを形成して原核生物か ら真核生物まで幅広く分布し, 哺乳類には, 少なくと も局在の異なる 6 種類の $\operatorname{Prx}$ が知られている7 . その うちの一つ, Prx I は, 肝臓など種々の組織に存在し, 細胞質で機能するタンパク質である. Prxの触媒する 反応は，活性中心にあるジスルフィド（S-S）結合が チオレドキシンなどの還元型チオール基によって還元 されることで活性型酵素としてペルオキシダーゼの反 応を触媒する.

ラット Prx I は, 肝臓からの粗抽出液のゲルろ過解 析の結果, 同一サブユニットが集合して多量体を形成
し，しかも多量体の形態に複数の状態（10 量体と 2 量体など）があることが示唆された. 細胞内において も多量体の存在形態に複数の状態があり, これが Prx Iの機能に深く関わっていると考えられた ${ }^{8}$.このPrx I $\mathrm{pET}$ vectorを用いて大腸菌内で発現させると， 大腸菌内で可溶性に回収された (Fig. 1, lane 5, 6). 発現量は非常に多く, 大腸菌の全可溶性タンパク質の $20 \%$ 以上を占めているものと考えられる（Fig. 2, A). 発現させたタンパク質を精製し, 高速液体クロ マトグラフィー (High performance liquid chromatography；HPLC）によるゲルろ過を行うと 10 量体と 2 量体のほかにも複数のピークが見られ(Fig. 3，A）, 肝臓の抽出物で見られた多量体構造の形成を示唆する 結果と一致していた。 10 量体のタンパク質画分を同 じゲルろ過カラムで再分画すると 10 量体に加え 2 量 体のピークが現れていることから，10 量体から 2 量 体への構造変換が起こりうることが示された（Fig. 3, B).

$\operatorname{Prx}$ I は一次構造上 4 カ所のシステイン残基 (Cys52, Cys71, Cys83, Cys173) を含んでおり，そ れらの中にペルオキシダーゼ活性に必要なシステイン 残基がある。これらの Cys 残基を部位特異的変異に よりセリン残基に変えた変異型タンパク質を調製し解 析した。その結果 2 つのシステイン残基 (Cys52, Cys 


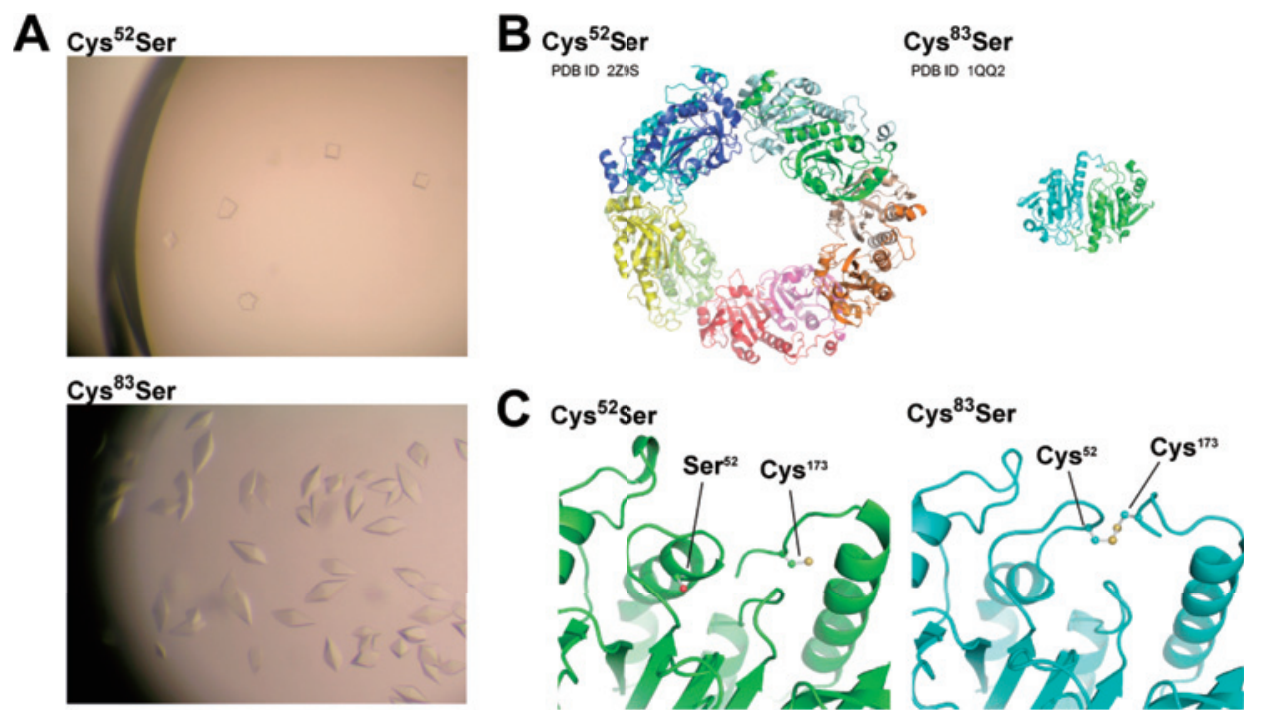

Fig. 4 変異型 Prx I の結晶構造解析

$\mathrm{A}$ : 変異型タンパク質の結晶.

B, C : X 線結晶構造解析により明らかになった Prx I の立体構造.

173）をセリン残基に変異させると, ペルオキシダー ゼ活性は峦失し，これらが活性中心であることが明ら かとなった ${ }^{8.9}$. 活性に重要な残基の機能解析にも大腸 菌の発現系を利用した組換えタンパク質は非常に有用 であることを示す一例である。

さらに, Cys52Ser 変異体は, ゲルろ過解析の結果 から大部分が 10 量体で存在することが分かった。ま たCys83 残基をセリンに変えた Cys83Ser 変異体は, Cys52Ser 変異体とは逆に 10 量体はほとんど存在せず 2 量体で安定的に存在することが分かった。これらの 変異体は野生型の Prx I で見られる多量体の構造変換 (10 量体から 2 量体へ, または 2 量体から 10 量体へ) がおこらなくなった結果, それぞれ 10 量体, 2 量体 の形態をとるものと考えられる. 野生型の Prx Iも含 め，いずれの組換えタンパク質も大量に精製できるた め, 結晶化による X 線結晶構造解析を試みたところ, 野生型酵素の結晶化は成功しなかったが, Cys52Ser, Cys83Ser 変異体の結晶化に成功し, それぞれ 10 量 体, 2 量体での立体構造が明らかになった（Fig. 4,

A, B). Cys52Ser 変異体の 10 量体の構造は 2 量体

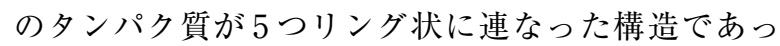
た.また，この 10 量体構造において，それぞれの 2 量体サブユニット同士が近接する領域に Cys83 残基 が存在しており，5 カ所の近接部位のうちの 1 つにサ ブユニット間でCys83 の S-S 結合が確認できた。こ のことから Cys83 残基が S-S 結合を介して Prx I の多 量体形成を安定化させる可能性が示唆された。 また, Cys83Ser の 2 量体構造では, 活性に重要な Cys52,
Cys173 残基が 2 つサブユニット間でジスルフィド （S-S）結合を形成した酸化型のPrx であった．Cys52 Ser 変異体では変異によりこの S-S 結合は形成できな いため, それぞれの構造は反応の中間体としての酸化 型，還元型の立体構造を示しているものと考えられる

(Fig. 4, C).

\section{おわりに}

近年, 多くの生物でゲノムの解読が終了し, 特定の 細胞でのタンパク質の発現変化などを調べる手段とし てトランスクリプトーム解析やプロテオーム解析に よって網羅的な解析が盛んに行われている．新たに見 つかったタンパク質は, アミノ酸配列や対応する遺伝 子の塩基配列からその機能や構造を推測することが可 能なこともあるが, 実際にその機能を明らかにするに は組換えタンパク質を調製して解析することが非常に 有効である.ここで示したペルオキシレドキシンの発 現系は非常に成功した例で，大腸菌で発現・精製する ことで, タンパク質の結晶化に供することが可能なほ ど大量に調製でき, 変異型酵素を作製することで動的 に高次構造が変化するタンパク質を特定の形態に偏ら せ安定な立体構造の解明に成功した。この成果は夕ン パク質の機能を分子レベルで議論し更なる研究の発展 につながるものである. 大腸菌での大量発現が可能で あるか否かについては, ある程度, 予測可能な場合も あるが, とにかく発現べクターを構築して発現を試み ることがよい．基本的に大腸菌内でタンパク質の発現 
を行うと，真核生物で見られるような翻訳後修飾はで きないので，特別な修飾が抢こるようなタンパク質，

具体的にはリン酸化や糖鎖修飾された形で大量に発現 させたい場合は，真核細胞を用いた発現系（バキュロ ウィルスを用いた昆虫細胞での発現系や酵母を用いた 発現系) を検討する必要がある。

\section{文 献}

1. Studier FW, Rosenberg AH, Dunn JJ, Dubendorff JW: Use of T7 RNA polymerase to direct expression of cloned genes. Methods Enzymol 1990; 185: 60-89.

2. Rosenberg AH, Lade BN, Chui DS, Lin SW, Dunn JJ, Studier FW: Vectors for selective expression of cloned DNAs by T7 RNA polymerase. Gene 1987; 56 : 125-135.

3. Studier FW, Moffatt BA: Use of bacteriophage T7 RNA polymerase to direct selective high-level expression of cloned genes. J Mol Biol 1986; 189: 113130.

4. Inouye $\mathrm{M}, \mathrm{Fu} \mathrm{X}$, Shinde $\mathrm{U}$ : Substrate-induced activation of a trapped IMC-mediated protein folding intermediate. Nat Struct Biol 2001; 8: 321-325.
5. Yamagata H, Nakahama K, Suzuki Y, Kakinuma A, Tsukagoshi N, Udaka S: Use of Bacillus brevis for efficient synthesis and secretion of human epidermal growth factor. Proc Natl Acad Sci U S A 1989; 86: 3589-3593.

6. Kaelin WG Jr, Krek W, Sellers WR, et al.: Expression cloning of a cDNA encoding a retinoblastomabinding protein with E2F-like properties. Cell 1992; 70: 351-364.

7. Hofmann B, Hecht HJ, Flohé L.: Peroxiredoxins. Biol Chem 2002; 383: 347-364. Review.

8. Matsumura T, Okamoto K, Abe Y, et al.: Dimeroligomer interconversion of wild-type and mutant rat 2-Cys peroxiredoxin: disulfide formation at dimerdimer interfaces is not essential for decamerization. J Biol Chem 2008; 283: 284-293.

9. Hirotsu S, Abe Y, Okada K, et al:: Crystal structure of a multifunctional 2-Cys peroxiredoxin hemebinding protein $23 \mathrm{kDa}$ /proliferation-associated gene product. Proc Natl Acad Sci U S A 1999; 96: 1233312338.

（受付：2011 年 9 月 1 日）

(受理 : 2011 年 9 月 7 日) 